\title{
FUZZY MULTI-ATRIBUTE DECISION MAKING (FUZZY MADM) DENGAN METODE SAW UNTUK PEMILIHAN MAHASISWA BERPRESTASI
}

\author{
Bernadus Very Christioko \\ Jurusan Teknologi Informasi \\ Universitas Semarang \\ Semarang, Indonesia \\ very@usm.ac.id
}

\author{
Henny Indriyawati \\ Jurusan Teknologi Informasi \\ Universitas Semarang \\ Semarang, Indonesia \\ henny@usm.ac.id
}

\author{
Nurtriana Hidayati \\ Jurusan Teknologi Informasi \\ Universitas Semarang \\ Semarang, Indonesia \\ anna@usm.ac.id
}

\begin{abstract}
Penentuan mahasiswa berprestasi (mawapres) tingkat fakultas terkadang mengalami kendala disaat penilaian kriteria tertentu pada kandidat kurang memenuhi namun di kriteria lain penilaian yang diperoleh melebihi ketentuan, juga apabila data-data atau informasi yang diberikan baik oleh juri maupun data kriteria dari kandidat tidak lengkap atau mengandung ketidakpastian yang mengakibatkan ketidakpastian nilai. Oleh karena itu tujuan dari penelitian ini adalah menerapkan metode Fuzzy untuk mengatasai ketidakpastian data atau informasi dan Multi-Attribute Decision Making (FMADM) dengan metode Simple Additive Weighting (SAW) untuk metode pengambilan keputusan dalam pemilihan mahasiswa berprestasi. Hasil dari penelitian ini adalah penerapan metode $F M A D M$ untuk mendukung pengambilan keputusan dalam pemilihan mahasiswa berprestasi tingkat fakultas dengan kandidat yang berasal dari setiap program studi.
\end{abstract}

Keywords-Fuzzy; MADM; SAW; Mawapres

\section{PENDAHULUAN}

Mawapres atau mahasiswa berprestasi adalah mahasiswa yang berhasil mencapai prestasi tinggi, baik kurikuler, kokurikuler, maupun ekstrakurikuler sesuai dengan kriteria yang ditentukan. Mahasiswa berprestasi ini tidak hanya menekuni ilmu dalam bidangnya saja di program studi yang mereka pilih namun juga beraktifitas dalam mengembangkan kemampuan soft skillnya. harapannya agar mahasiswa menjadi lulusan yang mandiri, penuh inisiatif, bekerja secara cermat, penuh tanggung jawab dan tangguh ketika menghadapi dunia kerja dan wirausaha [3].

Untuk memilih dan memberikan penghargaan serta memotivasi mahasiswa yang berprestasi ini pihak fakultas melakukan proses seleksi kepada beberapa kandidat mahasiswa berprestasi yang diambil dari masing-masing program studi dengan kriteria yang telah ditentukan. Proses penentuan mahasiswa berprestasi terkadang mengalami kendala disaat penilaian kriteria tertentu pada kandidat kurang memenuhi namun di kriteria lain penilaian yang diperoleh melebihi ketentuan, seperti contoh mahasiswa dengan nilai akademik yang tinggi tetapi tidak aktif dalam kegiatan kokurikuler dan ekstrakurikuler. Sebaliknya mahasiswa yang aktif dalam organisasi dan kegiatan pengembangan soft skills terkadang tidak memiliki nilai akademik yang tinggi. Untuk mengatasi ini diperlukan sebuah metode pengambilan keputusan untuk menentukan mahasiswa berprestasi terbaik di tingkat fakultas.
Multiple Criteria Decision Making (MCDM) adalah suatu metode pengambilan keputusan untuk menetapkan alternatif yang terbaik dari sejumlah alternatif berdasarkan kriteria tertentu. Berdasarkan tujuannya $M C D M$ dibagi menjadi 2 model: Multi Attribute Decision Making (MADM); dan Multi Objective Decision Making (MODM). MADM digunakan untuk melakukan seleksi terhadap beberapa alternatif dalam jumlah terbatas sedangkan $M O D M$ digunakan untuk merancang alternatif terbaik. Apabila data-data atau informasi yang diberikan baik oleh juri maupun data kriteria dari kandidat tidak lengkap atau mengandung ketidakpastian, maka untuk mengatasi masalah ketidakpastian ini digunakan metode fuzzy dalam MCDM yaitu Fuzzy MADM dan Fuzzy MODM [1][2].

Tujuan penelitian ini menggunakan metode Fuzzy MADM untuk menentukan mahasiswa berprestasi terbaik tingkat fakultas.

\section{METODE}

\section{A. Multi-Attribute Decision Making (MADM)}

$M A D M$ biasanya digunakan untuk melakukan penilaian atau seleksi terhadap beberapa alternatif dalam jumlah yang terbatas untuk menyeleksi alternatif terbaik dari sejumlah alternatif. Pendekatan pada metode $M A D M$ dilakukan melalui 2 tahap, yaitu:

1. Melakukan agregasi terhadap keputusan-keputusan yang tanggap terhadap semua tujuan pada setiap alternatif,

2. Melakukan perangkingan alternatif-alternatif keputusan tersebut berdasarkan agregasi keputusan.

Metode MADM mengevaluasi $\mathrm{m}$ alternatif $\mathrm{A}_{\mathrm{i}}(\mathrm{i}=$ $1,2, \ldots, \mathrm{m})$ terhadap sekumpulan atribut atau kriteria $C_{j}(j=$ $1,2, \ldots, n)$, dimana setiap atribut saling tidak bergantung satu dengan yang lainnya. Matriks keputusan setiap alternatif terhadap setiap atribut, $\mathrm{X}$, diberikan sebagai berikut:

$$
X=\left[\begin{array}{cccc}
x_{11} & x_{12} & \cdots & x_{1 n} \\
x_{21} & x_{22} & \cdots & x_{2 n} \\
\vdots & \vdots & & \vdots \\
x_{m 1} & x_{m 2} & \cdots & x_{m n}
\end{array}\right]
$$

dimana $x_{i j}$ merupakan rating kinerja alternatif ke-I terhadap atribut ke-j. Nilai bobot yang menunjukkan tingkat kepentingan relative setiap atribut, diberikan sebagai, $\mathrm{W}$ :

$$
W=\left\{w_{1}, w_{2}, \ldots, w_{n}\right\}
$$


Rating kinerja (X), dan nilai bobot (W) merupakan nilai utama yang merepresentasikan preferensi absolut dari pengambil keputusan. Masalah MADM diakhiri dengan proses perangkingan untuk mendapatkan alternatif terbaik yang diperoleh berdasarkan keseluruhan preferensi yang diberikan.

B. Metode Simple Additive Weighting (SAW)

Konsep dasar $S A W$ adalah mencari penjumlahan terbobot dari rating kinerja pada setiap alternatif pada semua atribut. Metode SAW membutuhkan proses normalisasi matrik keputusan (X) ke suatu skala yang dapat diperbandingkan dengan semua rating alternatif yang ada.

$r_{i j}= \begin{cases}\frac{x_{i j}}{\operatorname{Max} x_{i j}} & \text { jikajadalahatribut keuntungan (benefit) } \\ \operatorname{Min} x_{i j} & \\ \frac{i}{x_{i j}} & \text { jika jadalah atribut biaya (cost) }\end{cases}$

Dimana $r_{i j}$ adalah rating kinerja ternormalisasi dari alternatif $A_{i}$ pada atribut $C_{j}$, dimana $\mathrm{i}=1,2, \ldots \mathrm{m}$ dan $\mathrm{j}=1,2, \ldots, \mathrm{n}$. Nilai preferensi untuk setiap alternatif $\left(V_{i}\right)$ diberikan sebagai berikut:

$$
V_{i}=\sum_{j=1}^{n} w_{j} r_{i j}
$$

Nilai $\left(V_{i}\right)$ yang lebih besar mengindikasikan bahwa alternatif $A_{i}$ lebih terpilih.

\section{Fuzzy Multi-Attribute Decision Making (FMADM)}

FMADM merupakan salah satu model dari Fuzzy MCDM, dimana alternatif-alternatif sudah diketahui dan ditentukan kemudian pengambil keputusan menentukan prioritas atau ranking berdasarkan kriteria yang diberikan. Untuk menyelesaikan masalah FMADM, dibutuhkan 2 tahap, yaitu:

a. Membuat rating pada setiap alternatif berdasarkan agregasi derajat kecocokan pada semua kriteria.

b. Merangking semua alternatif untuk mendapatkan alternatif terbaik. Terdapat 2 cara yang dapat digunakan dalam proses perankingan, yaitu defuzzy atau melalui relasi preferensi fuzzy.

Metode MADM klasik SAW dapat digunakan untuk menyelesaikan masalah fuzzy MADM yang dipakai untuk melakukan perankingan, setelah terlebih dahulu dilakukan konversi data fuzzy ke data crisp. Apabila data fuzzy diberikan dalam bentuk linguistic, maka harus dikonversi terlebih dahulu ke bentuk bilangan fuzzy, baru kemudian dikonversi kembali ke bilangan crisp.

Berikut tahapan-tahapan dalam pengambilan keputusan menggunakan FMADM

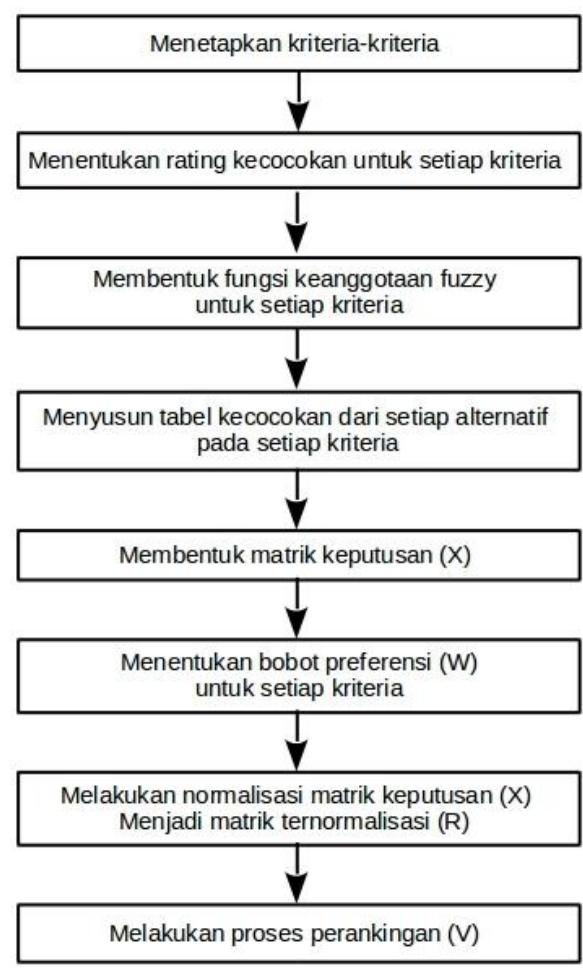

Gambar. 1 Tahapan FMADM

\section{HASIL DAN PEMBAHASAN}

\section{A. Penetapan Kriteria-Kriteria}

Kriteria yang digunakan untuk menentukan mahasiswa berprestasi adalah sebagai berikut:
1. $\operatorname{IPK}(\mathrm{C} 1)$
2. Karya Tulis Ilmiah (C2)
3. Prestasi/kemampuan yang diunggulkan (C3)
4. Bahasa Inggris/Asing (C4)

\section{B. Penentuan Rating Kecocokan Setiap Kriteria}

Penentuan rating kecocokan setiap alternatif pada setiap kriteria dimulai dari 0 sampai 1 , tampak seperti tabel berikut.

TABEL 1 Bobot Indeks Prestasi Kumulatif

\begin{tabular}{|c|c|}
\hline NILAI IPK & NILAI \\
\hline IPK $\leq 2,75$ & 0 \\
\hline $2,75<X \leq 3,00$ & 0,25 \\
\hline $3,00<X \leq 3,25$ & 0,5 \\
\hline $3,25<X \leq 3,50$ & 0,75 \\
\hline IPK $>3,50$ & 1 \\
\hline
\end{tabular}


TABEL 2 Bobot Karya Tulis Ilmiah

\begin{tabular}{|c|c|}
\hline $\begin{array}{c}\text { NILAI KARYA } \\
\text { ILMIAH }\end{array}$ & NILAI \\
\hline Nilai $\leq 50$ & 0 \\
\hline $60<\mathrm{X} \leq 70$ & 0,25 \\
\hline $70<\mathrm{X} \leq 80$ & 0,5 \\
\hline $80<\mathrm{X} \leq 90$ & 0,75 \\
\hline Nilai $>90$ & 1 \\
\hline
\end{tabular}

TABEL 3 Bobot Prestasi/ kemampuan yang diunggulkan

\begin{tabular}{|c|c|}
\hline NILAI PRESTASI & NILAI \\
\hline Nilai $\leq 50$ & 0 \\
\hline $60<\mathrm{X} \leq 70$ & 0,25 \\
\hline $70<\mathrm{X} \leq 80$ & 0,5 \\
\hline $80<\mathrm{X} \leq 90$ & 0,75 \\
\hline Nilai $>90$ & 1 \\
\hline
\end{tabular}

TABEL 4 Bobot Kemampuan Bahasa Inggris

\begin{tabular}{|c|c|}
\hline $\begin{array}{c}\text { NILAI } \\
\text { KEMAMPUAN } \\
\text { BERBAHASA } \\
\text { INGGRIS }\end{array}$ & NILAI \\
\hline Nilai $\leq 50$ & \\
\hline $60<\mathrm{X} \leq 70$ & 0,25 \\
\hline $70<\mathrm{X} \leq 80$ & 0,5 \\
\hline $80<\mathrm{X} \leq 90$ & 0,75 \\
\hline Nilai $>90$ & 1 \\
\hline
\end{tabular}

C. Membentuk Fungsi Keanggotaan Fuzzy

Masing-masing kriteria kemudian dibuat suatu variabel. Variabel yang telah ditetapkan akan dirubah dalam bilangan fuzzy. Bilangan fuzzy yang terbentuk adalah:

Sangat Rendah $(\mathrm{SR})=0$

Rendah $(\mathrm{R})=0,25$

Sedang $(S)=0,5$

Tinggi $(\mathrm{T})=0,75$

Sangat Tinggi $($ ST $)=1$

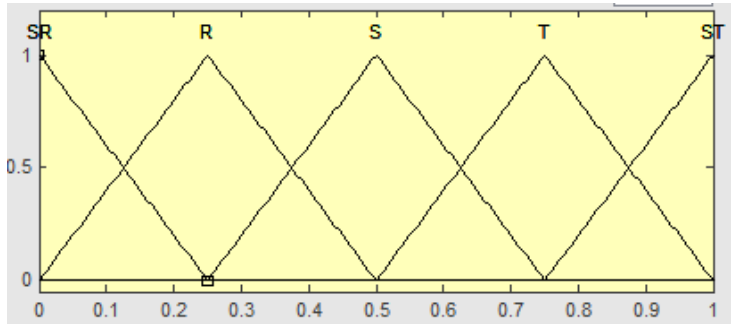

Gambar. 2 Fungsi Keanggotaan tiap kriteria

D. Menyusun Tabel Rating Kecocokan

Alternatif-alternatif mahasiswa berprestasi diberi rating kemudian menyusun tabel kecocokan dari setiap kriteria lalu disajikan dalam table berikut:

TABEL 5 Rating kecocokan dari setiap alternatif pada setiap kriteria

\begin{tabular}{|c|c|c|c|c|}
\hline \multirow{2}{*}{ NAMA } & \multicolumn{4}{|c|}{ Kriteria } \\
\cline { 2 - 5 } & C1 & C2 & C3 & C4 \\
\hline Mahasiswa A & 0.5 & 0.5 & 0.5 & 0.5 \\
\hline Mahasiswa B & 0.5 & 0.25 & 0.5 & 0.5 \\
\hline Mahasiswa C & 0.75 & 0.25 & 0.5 & 0.75 \\
\hline Mahasiswa D & 0.5 & 1 & 0.75 & 0.75 \\
\hline Mahasiswa E & 0.75 & 0.5 & 0.5 & 0.25 \\
\hline ... & $\ldots$ & $\ldots$ & $\ldots$ & $\ldots$ \\
\hline Mahasiswa T & 0.75 & 0.5 & 0.5 & 0.5 \\
\hline
\end{tabular}

E. Membentuk Matrik Keputusan (X)

Matrik keputusan dibentuk sesuai dengan tabel kecocokan dan fungsi keanggotaan himpunan fuzzy berdasarkan persamaan 1. Sebagai contoh matrik berikut diambil secara acak dari keseluruhan data alternative yang ada.

$$
\text { Matrik X }=\left(\begin{array}{llll}
0,5 & 1 & 0,75 & 0,75 \\
0,5 & 0,75 & 0,5 & 0,5 \\
0,75 & 1 & 1 & 0,75 \\
0,5 & 0,5 & 0,5 & 0,5 \\
0,25 & 0,5 & 0,5 & 0,5
\end{array}\right)
$$

F. Menentukan Bobot preferensi (W) untuk setiap kriteria Bobot preferensi ditentukan sesuai pengambil keputusan yaitu:
a) IPK C1 $=0,5$
b) Karya Tulis Ilmiah $(\mathrm{C} 2)=1$
c) Prestasi/kemampuan yang diunggulkan $(\mathrm{C} 3)=0,75$
d) Bahasa Inggris/Asing $(\mathrm{C} 4)=0,5$

$$
\text { Vektor Bobot }(\mathrm{W})=\left[\begin{array}{llll}
0,5 & 1 & 0,75 & 0,5
\end{array}\right]
$$


G. Melakukan Normalisasi Matrik Keputusan (X)

Matrik keputusan dinormalisasi menjadi matrik ternormalisasi (R) berdasarkan persamaan 3. Berikut contoh hasil normalisasi untuk data mahasiswa berprestasi yang dipilih pada tahap sebelumya.

Normalisasi matrik X sebagai berikut:

$$
\begin{aligned}
& r 11=\frac{0,5}{\operatorname{Max}[0,5 ; 0,5 ; 0,75 ; 0,5 ; 0,5]}=\frac{0,5}{0,75}=0,67 \\
& r 12=\frac{0,5}{\operatorname{Max}[0,5 ; 0,5 ; 0,75 ; 0,5 ; 0,5]}=\frac{0,5}{0,75}=0,67 r 13= \\
& \frac{0,75}{\operatorname{Max}[0,5 ; 0,5 ; 0,75 ; 0,5 ; 0,5]}=\frac{0,75}{0,75}=1 r 14= \\
& \frac{0,5}{\operatorname{Max}[0,5 ; 0,5 ; 0,75 ; 0,5 ; 0,5]}=\frac{0,5}{0,75}=0,67
\end{aligned}
$$

dst ...

Hasil matrik ternormalisasi R sebagai berikut:

$$
\text { Matrik R }=\left(\begin{array}{llll}
0,67 & 1 & 0,75 & 1 \\
0,67 & 0,75 & 0,5 & 0,67 \\
1 & 1 & 1 & 1 \\
0,67 & 0,5 & 0,5 & 0,67 \\
0,33 & 0,5 & 0,5 & 0,67
\end{array}\right)
$$

\section{H. Melakukan Proses Perankingan (V)}

Proses perankingan dilakukan berdasarkan persamaan 4 dari hasil yang diperoleh di tahap sebelumnya

Proses Perangkingan yang dihasilkan adalah sebagai berikut:

$$
\begin{aligned}
& \mathrm{V} 1=(0,5)(0,67)+(1)(1)+(0,75)(0,75)+(0.5)(1)=2,39 \\
& \mathrm{~V} 2=(0,5)(0,67)+(1)(0,75)+(0,75)(0,5)+(0.5)(0,67)=
\end{aligned}
$$

$\mathrm{V} 3=(0,5)(1)+(1)(1)+(0,75)(1)+(0.5)(1)=2,75$

$\mathrm{V} 4=(0,5)(0,67)+(1)(0,5)+(0,75)(0,5)+(0.5)(0,67)=$

$$
1,54
$$$$
\text { V5 }=(0,5)(0,33)+(1)(0,5)+(0,75)(0,5)+(0.5)(0,67)=
$$

Hasil perankingan pada seluruh data mahasiswa berprestasi yang kemudian diurutkan berdasarkan nilai yang terbesar seperti tampak pada tabel 6 berikut ini:
TABEL 6 Hasil Perangkingan

\begin{tabular}{|c|c|c|c|c|c|}
\hline NAMA & C1 & C2 & C3 & C4 & Nilai \\
\hline Mahasiswa I & 0,75 & 1 & 1 & 0,75 & 2.750 \\
\hline Mahasiswa D & 0,5 & 1 & 0,75 & 0,75 & 2.396 \\
\hline Mahasiswa R & 0,5 & 0,75 & 0,75 & 0,75 & 2.146 \\
\hline Mahasiswa O & 0,5 & 0,5 & 1 & 0,5 & 1.917 \\
\hline Mahasiswa F & 0,5 & 0,75 & 0,5 & 0,5 & 1.792 \\
\hline ... & $\ldots$ & $\ldots$ & $\ldots$ & $\ldots$ & $\ldots$ \\
\hline Mahasiswa E & 0,75 & 0,5 & 0,5 & 0,25 & 1.542 \\
\hline
\end{tabular}

\section{KESIMPULAN DAN SARAN}

A. Kesimpulan

Berdasarkan hasil dari tahapan-tahapan dalam penelitian ini dapat diambil kesimpulan sebagai berikut:

1) Kriteria-kriteria mahasiswa berprestasi dapat di representasikan ke dalam Fuzzy MADM untuk pemilihan mahasiswa berprestasi.

2) Model pengambilan keputusan dalam menentukan mahasiswa berprestasi menggunakan metode MADM dapat menghasilkan hasil yang akurat yaitu sesuai dengan ketentuan.

\section{B. Saran}

Hasil penelitian ini masih memiliki beberapa kekurangan, untuk itu peneliti memberikan saran untuk penelitian selanjutnya sebagai berikut:

1) Menggunakan metode MADM yang lain dalam menentukan mahasiswa berprestasi terbaik.

2) Mengembangkan sistem yang lengkap untuk menerapkan model pengambilan keputusan menggunakan metode MADM..

\section{DAFTAR PUSTAKA}

[1] Kusumadewi, Sri and Purnomo, Hari., 2010, Aplikasi Logika Fuzzy untuk Pendukung Keputusan, Yogyakarta : Graha Ilmu.

[2] Kusumadewi, Sri, dkk., 2006, Fuzzy Multi-Attribute Decision Making (FUZZY MADM), Yogyakarta : Graha Ilmu.

[3] Republik Indonesia, 2015, Pedoman Pemilihan Mahasiswa Berprestasi Program Sarjana, Jakarta: Direktorat Jenderal Pembelajaran dan Kemahasiswaan Kementerian Riset, Teknologi dan Pendidikan TInggi 